\title{
Manajemen Layanan Pendidikan Islam
}

\author{
Teddy Rusdi \\ MIN 2 Kota Mataram \\ Teddy_naufal@ymail.com
}

\begin{abstract}
Abstrak: Lembaga pendidikan baik negeri maupun swasta harus memperhatikan layanan pendidikan terbaik yang mampu diberikan oleh semua warga madrasah/sekolah. Memberikan pelayanan yang maksamal akan memberikan kenyamanan dan kepercayaan yang tinggi masyarakat terhadap lembaga tersebut, seorang kepala madrasah harus mampu memberikan pelayanan pembelajaran, pelayanan kepegawaian, pelayanan keuangan dan pelayanan kesejahteraan atau dengan kata lain kepala madrasah harus memberikan pelayanan yang terbaik kepada orang lain baik jajaran pimpinan, para guru, siswa, para karyawan, para wali murid, para pengguna lulusan dan masyarakat luas. Madrasah atau lembaga pendidika Islam dikatakan berhasil apabila mamapu memberikan layanan yang sama atau melebihi harapan pelanggan seperti peserta didik puas dengan layanan mandrasah, misalnya puas dengan pelajaran yang diterima, puas dengan perlakuan guru, dan puas dengan fasilitas yang disediakan madrasah, intinya peserta didik menikmati situasi di madrasah, orang tua puas dengan layanan terhadap anaknya maupun layanan kepada orang tua. Misalnya, puas karena menerima laporan periodik tentang perkembangan peserta didik maupun program-program madrasah, pihak penerima lulusan (perguruan tinggi, industri dan masyarakat) puas karena menerima lulusan dengan kualitas sesuai dengan harapan, guru dan karyawan puas dengan pelayanan madrasah, misalnya dalam pembagian kewajiban kerja, hubungan antar guru/karyawan/pimpinan, honorarium/gaji dan sebagainya.
\end{abstract}

Kata kunci: Manajemen, layanan pendidikan Islam

\section{Pendahuluan}

Upaya penyelenggaraan pendidikan Islam yang formal yang bermutu sangat berkaitan erat dengan kejelian dan ketepatan dalam mengidentifikasi, memformulasi, mengemas, serta menjabarkan kebijakan, strategis dan program operasional pendidikan. Ini berarti bahwa kemampuan manajerial kepala sekolah dan layanan 
profesional tenaga pendidikan perlu dikembangkan dan difungsikan secara optimal. Oleh sebab itu sekolah sebagai unit kerja terdepan yang langsung berhubungan dengan kebutuhan riil di bidang pendidikan, sudah saatnya untuk memiliki otonomi kerja dalam menjalankan manajemen di sekolahnya. Di bawah kepemimpinan kepala sekolah yang profesional, mereka diharapkan mampu menampilkan dan mengembangkan diri serta memberikan pelayanan yang maksimal sesuai dengan potensi yang pada gilirannya dapat meningkatkan mutu pendidikan di Institusinya. Dengan demikian kepercayaan masyarakat terhadap lembaga pendidikan Islam yang formal menjadi semakin meningkat.

Layanan merupakan persoalan yang serius bagi para manajer, termasuk manajer pendidikan Islam. Ini terutama ketika mereka menghendaki peningkatan di segala bidang sebagai modal dasar dalam memajukan lembaga pendidikan yang dikendalikannya. Terlebih lagi bagi manajer yang merencanakan lembaganya bisa mengungguli lembaga lain tentu pelayanan menjadi salah satu komponen pengelolaan pendidikan yang harus mendapat perhatian khusus. ${ }^{1}$ Pelayanan dalam pendidikan Islam mencakup berbagai hal, seperti pelayanan pembelajaran, pelayanan kepegawaian, pelayanan keuangan dan pelayanan kesejahteraan.

Falsafah yang harus diimplementasikan oleh manajer lembaga pendidikan Islam adalah falsafah penjual. Sebagai penjual yang baik ada sikap-sikap tertentu yang ditampilkan keada para pembeli, antara lain; (1) Berusaha memberikan pelayanan dengan cepat dan tepat, berusaha bersikap ramah, (3) Berusaha mematok harga yang bersaing, (4) Berusaha mengibur pembeli, (5) Berusaha bersikap jujur, dan (6) Berusaha mampu menahan diri dari perasaan kecewa jika ada pembeli yang bersikap kurang menyenangkan. ${ }^{2}$

Prilaku penjual ini harus dikondisikan kepada seluruh individu yang terlibat pengelolaan lembaga pendidikan Islam, mulai dari manajer puncak, manajer madya dan manajer terendah, hingga staf-staf paling bawah sekalipun. Mereka harus memiliki satu tekad yang sama untuk memberikan pelayanan yang terbaik kepada siapa saja, baik melalui ucapan maupun tindakan.

${ }^{1}$ Mujmil Qomar, Manajemen Pendidikan Islam, (Malang: PT. Erlangga, 2007), 193.

${ }^{2}$ Ibid, Manajemen ..., 195. 
Dari uaraian pendahuluan di atas, maka dalam tulisan ini permasalahan yang akan di bahas adalah apa yang dimaksud dengan manajeman layanan pendidikan Islam?

\section{Manajemen Layanan Pendidikan Islam}

Layanan merupakan hal yang serius bagi para manajer, termasuk manajer pendidikan Islam. Hal ini dilakukan guna meningkatkan pelayanan lembaga pendidikan yang dikendalikannya. Terkadang untuk menentukan maju tidaknya suatu lembaga pendidikan dapat pula di lihat bagaimana mutu pelyanan yang diberikan oleh kepala sekolah, guru, staf tata usaha terhadap siswa, orang tua, dan tamu yang berkunjung.

Firman Allah dalam Surat Al-Hasyr: 9

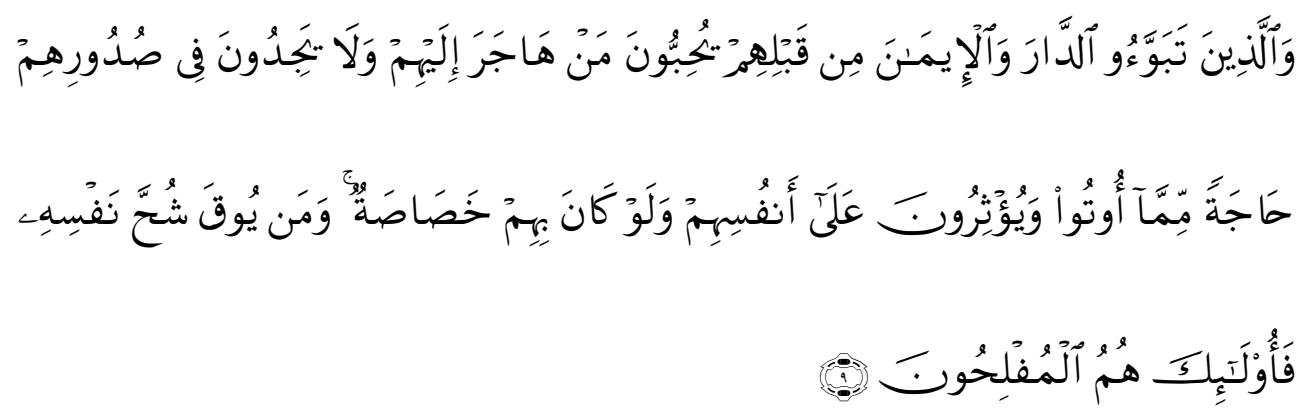

“ Dan orang-orang yang telah menempati kota Madinah dan telah beriman (Anshor) sebelum (kedatangan) mereka (Muhajirin), mereka (Anshor) 'mencintai' orang yang berhijrah kepada mereka (Muhajirin). dan mereka (Anshor) tiada menaruh keinginan dalam hati mereka terhadap apa-apa yang diberikan kepada mereka (Muhajirin); dan mereka mengutamakan (orang-orang muhajirin), atas diri mereka sendiri, Sekalipun mereka dalam kesusahan. dan siapa yang dipelihara dari kekikiran dirinya, mereka Itulah orang orang yang beruntung”.

Ada beberapa konsekuensi dari ayat tersebut, yaitu: (1) Adanya usaha untuk menghormati atau melayani orang lain (dalam konteks ini kaum Muhajirin); (2) Kaum Anshor rela dengan apa yang diberikan kepada kaum Muhajirin; (3) Kaum Anshor mengutamakan penghormatan kepada kaum Muhajirin; dan Kaum Anshor rela mengalahkan kepentingannya sendiri. 
Ayat tersebut dapat mengilhami sikap atau prilaku para manajer pendidikan Islam. Mereka dapat meneladani sikap kaum Anshor dalam berinteraksi dengan kaum Muhajirin. Yang mencerminkan nilai-nilai pengorbanan. Dalam konteks manajemen pendidikan Islam, nilai-nilai pengorbanan bisa berupa :

a) Kesadaran untuk mengendalikan kepentingan diri sendiri

b) Kesadaran untuk mengutamakan kepentingan orang lain

c) Kesadaran untuk memuaskan orang lain

d) Kesadaran untuk menghindarkan kekecewaan orang lain sejauh mungkin

e) Kesadaran untuk membangkitkan perasan orang lain agar mencintai lembaga pendidikan Islam.

Oleh karena itu paradigma yang perlu dijadikan pegangan bagi para menajer lembaga pendidikan Islam, baik kapasitasnya sebagai kepala madrasah, pengasuh/kiyai pesantren, ketua jurusan, dekan, maupun rektor adalah sebagai pelayan umat. Yang berarti mereka harus memberikan pelayanan yang terbaik kepada orang lain baik jajaran pimpinan, para guru, siswa, para karyawan, para wali murid, para pengguna lulusan dan masyarakat luas.

Pelayanan dalam pendidikan Islam mencakup berbagai hal, seperti pelayanan pembelajaran, pelayanan kepegawaian, pelayanan keuangan dan pelayanan kesejahteraan. Kesejahteraan bisa diartikan dalam ukuran material, misalnya gaji, honorarium dan fasilitas fisik. Bisa juga diartikan dalam ukuran nonmaterial yang mengarah kepada kepuasan kerja. Personalia sekolah/madrasah merupakan orang terdidik, sehingga kesejahteraan nonmaterial seringkali sangat diperlukan. Untuk itu diperlukan hal-hal berikut ini :

a) Memberikan apa yang menjadi hak guru dan sifat administrasi, misalnya gaji, honorarium kelebihan jam mengajar/lembur, dan kenaikan pangkat tepat pada waktunya.

b) Memberikan penghargaan baik berupa material maupun nonmaterial bagi staf yang berprestasi atau telah mengerjakan tugas dengan baik.

c) Membina hubungan kekeluargaan antara para guru, staf beserta keluarganya

d) Mengupayakan kesejahteraan guru dalam RAPBS sepanjang tidak menyalahi aturan yang berlaku. 
e) Memberikan kesempatan dan memfasilitasi agar setiap staf dapat mengaktualisasikan potensinya. Caranya dengan memberi kesempatan untuk mengajukan gagasan kemudian mewujudkannya. ${ }^{3}$

Oleh karena itu, menurut Mulyasa, kesejahteraan guru tidak dapat diabaikan. Karena, ini merupakan salah satu faktor penentu dalam peningkatan kinerja, yang secara langsung berpengaruh terhadap mutu pendidikan. Peningkatan kesejahteraan guru dapat dilakukan antara lain dengan pemberian insentif di luar gaji, imbalan, penghargaan serta tunjangan yang dapat meningkatkan kinerja. ${ }^{4}$

Dalam konteks manajemen layanan ini, manajer pendidikan Islam harus bersikap adil dan proporsional kendati ada perhatian khusus pada para guru. Manajer harus berpikir general, yakni berusaha secara maksimal untuk memberikan pelayanan terbaik kepada siapa pun sesuai dengan potensi yang dimilikinya. Sebab sebagai unit layanan jasa, ada banyak pelanggan yang harus dilayani oleh para pelaksana pendidikan.

Pelanggan pendidikan terdiri atas dua jenis. Ada pelanggan internal dan pelangan eksternal. Sementara itu, pelanggan eksternal terdiri atas pelanggan primer, skunder, dan tersier. Dalam Panduan Manajemen Sekolah telah dirinci para pelaku masing-masing pelanggan itu sebagai berikut :

a. Pelanggan Internal terdiri atas guru, pustakawan, laboran, teknisi dan tenaga administrasi

b. Pelanggan Eksternal, yang merupakan pelanggan primer, yaitu siswa; pelanggan skunder yaitu orang tua, pemerintah dan masyarakat; dan pelanggan tersier, yaitu pemakai atau penerima lulusan baik lembaga pendidikan yang lebih tinggi maupun dunia usaha. ${ }^{5}$

Dalam manajemen layanan, manajer harus berusaha memberikan pelayanan terbaik kepada semua pelanggan dengan menggerakkan semua pimpinan dan staf untuk memberikan kepuasan kepada semua pihak melalui berbagai cara. Sebagai kepala madrasah setidaknya ada beberapa hal yang harus dilakukan agar pelanggan

${ }^{3}$ Departemen Pendidikan dan Kebudayaan Direktorat Jendral Pendidikan Dasar dan Menengah Direktorat, Panduan Manajemen Sekolah, (ttp.1998), 71-72.

${ }^{4}$ E. Mulyasa, Menjadi Kepala Sekolah Profesional dalam Konteks Menyukseskan MBS dan KBK.,(Bandung: PT. Remaja Rosdakarya, 2003), 79.

${ }^{5}$ Ibid, Departemen Pendidikan dan Kebudayaan Direktorat Jendral Pendidikan Dasar dan Menengah Direktorat, Panduan..., 170-171. 
merasa puas, yakni memberikan layanan sesuai dengan yang dijanjikan (reliability), mampu menjamin kwalitas pembelajaran (assurance), iklim madrasah yang kondusif (tangible), memeberikan perhatian penuh pada peserta didik (emphaty), dan cepat tanggap terhadap kebutuhan peserta didik (responsibility). ${ }^{6}$

Manajer dengan begitu dituntut mampu memberikan kepuasan terhadap pelanggan eksternal dan internal. Kedua pelangan tersebut memiliki hubungan timbal balik dan saling membutuhkan. Apabila pelanggan internal dilayani dengan baik kemudian mereka merasa puas, maka pelayanan yang diterimanya akan menjadi faktor terbentuknya sikap-sikap profesional dalam bekerja, seperti meningkatkan kinerja, meningkatkan loyalitas, meningkatkan kedisiplinan dan sebagainya. Untuk selanjutnya apabila pelanggan eksternal dilayani dengan baik dan mereka merasakan kepuasan, maka akan menumbuhkan kepercayaan yang tinggi pada eksistensi lembaga, bahkan mereka akan memberikan dukungan riil.

Ini berarti, usaha manajer memberikan pelayanan terbaik kepada pelanggan internal maupun eksternal merupakan upaya membangun kekuatan lembaga dari dalam dan luar. Kekuatan dari dalam diperlukan untuk memberikan jaminan terhadap proses pembelajaran dan tentunya juga kualitas pendidikan. Sementara itu, kekuatan dari luar dibutuhkan untuk memberikan pengakuan lalu dukungan terhadap pelaksanaan pendidikan. Dua kekuatan besar itu harus senantiasa dikondisikan oleh manajer pendidikan Islam guna memperkuat posisi akademik dan posisi popularitas lembaga pendidikan Islam.

Madrasah atau lembaga pendidika Islam dikatakan berhasil apabila mamapu memberikan layanan yang sama atau melebihi harapan pelanggan. Dilihat dari jenis pelanggannya, lembaga pendidikan Islam dikatakan berhasil jika :

1. Peserta didik puas dengan layanan mandrasah, misalnya puas dengan pelajaran yang diterima, puas dengan perlakuan guru, dan puas dengan fasilitas yang disediakan madrasah, intinya peserta didik menikmati situasi di madrasah;

2. Orang tua puas dengan layanan terhadap anaknya maupun layanan kepada orang tua. Misalnya, puas karena menerima laporan periodik tentang perkembangan peserta didik maupun program-program madrasah;

\footnotetext{
${ }^{6}$ Jamal Madhi, Menjadi Pemimpin yang Efektif dan Berpengarub Tujuan Manajemen Kepemimpinan Islam, Terj. Amang Syafrudin dan Ahmad Fauzan, (Bandung: PT Syaamil Cipta Media, 2002), 28.
} 
3. Pihak pemakai/penerima lulusan (perguruan tinggi, industri dan masyarakat) puas karena menerima lulusan dengan kualitas sesuai dengan harapan;

4. Guru dan karyawan puas dengan pelayanan madrasah, misalnya dalam pembagian kewajiban kerja, hubungan antar guru/karyawan/pimpinan, honorarium/gaji dan sebagainya. ${ }^{7}$

Guna mewujudkan keberhasilan tersebut, sebuah lembaga pendidikan Islam harus memperhatikan hal-hal sebagai berikut:

a. Berusaha memuaskan peserta didik dengan melengkapi fasilitas belajar, meningkatkan profesionalisme guru, mengkondisikan lingkungan belajar yang kondusif, memberikan jaminan rasa aman, nyaman dan tentram serta menghadirkan situasi pembelajaran yang menghibur

b. Berusaha memuaskan pegawai dengan cara meningkatkan kesejahteraan, perhatian dan hubungan harmonis dengan mereka, memperlancar peningkatan karier mereka.

c. Berusaha menyakinkan orang tua peserta didik bahwa anak-anaknya terjamin keamanannya, kemampuan intelektualnya, kepribadiannya, keimanannya dan akhlaknya melalui berbagai program bimbingan yang dilaksanakan oleh lembaga pendidikan Islam.

d. Berusaha membuktikan kemampuan peserta didik dan para alumni yang andal kepada para pengguna lulusan baik lembaga yang lebih atas, perguruan tinggi, industri maupun negara.

e. Berusaha mewujudkan lingkungan lembaga pendidikan yang Islami yang benarbenar Islami, cerdas, anggun, asri, dan mempesona kepada masyarakat. ${ }^{8}$

Dengan demikian manajemen layanan sangat perlu diperhatikan oleh lembaga pendidikan Islam, karena akan dapat meningkatkan kepercayaan masyarakat terhadap madrasah, sehingga dengan peningkatan kepercayaan tersebut akan dapat meningkatkan mutu pendidikan lembaga.

Kesimpulan

${ }^{7}$ Ibid,...., hal. 171-172

${ }^{8}$ Mujamil Qomar, Manajemen ..., 203. 
Layanan merupakan persoalan yang serius bagi para manajer, termasuk manajer pendidikan Islam. Ini terutama ketika mereka menghendaki peningkatan di segala bidang sebagai modal dasar dalam memajukan lembaga pendidikan yang dikendalikannya. Terlebih lagi bagi manajer yang merencanakan lembaganya bisa mengungguli lembaga lain tentu pelayanan menjadi salah satu komponen pengelolaan pendidikan yang harus mendapat perhatian khusus.

Pelayanan dalam pendidikan Islam mencakup berbagai hal, seperti pelayanan pembelajaran, pelayanan kepegawaian, pelayanan keuangan dan pelayanan kesejahteraan. Tugas dari lembaga pendidikan Islam adalah memberikan pelayanan maksimal pada para pelanggan.

Pelanggan pendidikan terdiri atas dua jenis. Ada pelanggan internal dan pelangan eksternal. Sementara itu, pelanggan eksternal terdiri atas pelanggan primer, skunder, dan tersier 


\section{DAFTAR PUSTAKA}

Baharuddin dan Moh. Makin. 2010. Manajemen Pendidikan Islam Transpormasi Menuju Sekolah/Madrasah Unggulan, Malang: UIN Maliki Press.

Departemen Pendidikan dan Kebudayaan Direktorat Jendral Pendidikan Dasar dan Menengah Direktorat. 1998. Panduan Manajemen Sekolah, ttp.

E. Mulyasa. 2002. Manajemen Berbasis Sekolah, Konsep, Strategi dan Implementasi, .,Bandung: PT. Remaja Rosdakarya.

2003. Menjadi Kepala Sekolah Profesional dalam Konteks Menyukseskan MBS dan KBK.,Bandung: PT. Remaja Rosdakarya.

Jamal Madhi. 2002. Menjadi Pemimpin yang Efektif dan Berpengarub Tujuan Manajemen Kepemimpinan Islam, Terj. Amang Syafrudin dan Ahmad Fauzan, Bandung: PT Syaamil Cipta Media.

Made Pidarta. 1998. Manajemen Pendidikan Indonesia, Jakarta: Bina Akara.

Mujmil Qomar. 2007. Manajemen Pendidikan Islam,Malang: PT. Erlangga.

Undang-Undang RI No. 20 Tahun 2003 tentang Sistem Pendidikan Nasional ttp, Pustaka Widyatama, tt. 